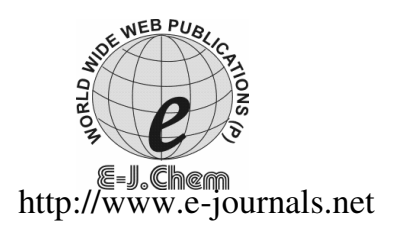

ISSN: 0973-4945; CODEN ECJHAO

E-Journal of Chemistry

2010, 7(4), 1523-1529

\title{
Spectrphotometric Determination of Buclizine as Hydrochloride Using Various Chromogenic Reagents
}

\author{
V. ANNAPURNA, G. JYOTHI, \\ A.V.SUBBAYAMMA and B.B.V. SAILAJA* \\ Department of Chemistry, St. Theresa's College for Women, Eluru-534003, India. \\ *Andhra University, Visakhapatnam, Andhra Pradesh, India. \\ sailaja_bbv@yahoo.co.in
}

Received 28 August 2009; Revised 31 December 2009; Accepted 20 February 2010

\begin{abstract}
Simple, accurate and reproducible UV spectrophotometric methods were established for the assay of buclizine (BUCZ) based on the formation of precipitation, charge transfer complex and inner complex formation. Method A involves the precipitation, charge transfer complex formation of BUCZ with tannic acid/ $p$ - $N$-methyl aminophenol sulphate (PMAP)-Cr(VI), the complex formation with cobalt thiocyanate (CTC) in method B and inner complex formation of BUCZ with sodium nitroprusside hydroxylamine hydrochloride and sodium carbonate in method $\mathrm{C}$ were proposed. The optical characteristics such as Beers law limits, molar absorptivity and Sandell's sensitivity for the methods (AC) are given. Regression analysis using the method of least squares was made to evaluate the slope(b), intercept(a) and correlation coefficient (r) and standard error of estimation (Se) for each system Determination of BUCZ in bulk form and in pharmaceutical formulations were also incorporated.
\end{abstract}

Keywords: Estimation, Buclizine, Precipitating agent, Charge transfer complex.

\section{Introduction}

Buclizine $^{1}$ (as hydrochloride, BUCZ) is a piperazine antihistamine with antimuscarinic and central sedative properties. It is mainly used for its anti-emetic action, particularly in the prevention of motion sickness when it should be given at least $30 \mathrm{~min}$. before traveling. It is also used in combination with analgesics to treat migraine attacks.

A very few physicochemical methods appeared in the literature for the assay of the proposed drug samples in biological fluids and pharmaceutical formulations. Most of them are based on visible spectrophotometric methods ${ }^{2,3}, \mathrm{HPLC}^{4-6}, \mathrm{GC}^{7,8}$, fluorimetry ${ }^{9-11}, \mathrm{LC}^{-\mathrm{MS}^{12}}{ }^{12}$ $\mathrm{GC}^{-M S^{13-15}}$ and $\mathrm{TLC}^{16}$, mass ${ }^{17}$. Existing analytical methods reveal that relatively little 
attention was paid in developing visible spectrophotometric methods by exploiting the analytically useful functional groups. Hence there is a need to develop sensitive and flexible visible spectrophotometric methods which prompted the author to carry out in this accord.

\section{Experimental}

An Elico, UV - Visible digital spectrophotometer with $1 \mathrm{~cm}$ matched quartz cells were used for the spectral and absorbance measurements. An Elico LI-120 digital pH meter was used for $\mathrm{pH}$ measurements.

All the chemicals and reagents used were analytical grade and the aqueous solutions were freshly prepared with triple distilled water. A $1 \mathrm{mg} / \mathrm{mL}$ solution was prepared by dissolving $100 \mathrm{mg}$ of pure BUCZ in $5 \mathrm{~mL}$ of $0.1 \mathrm{~N} \mathrm{HCl}$ followed by dilution to $100 \mathrm{~mL}$ with distilled water and the stock solution was diluted step wise with distilled water to get the working standard solutions of required concentrations. TA solution (Loba $0.2 \%, 1.17 \times 10^{-3} \mathrm{M}$ ); PMAP solution, (Loba, $\left.0.3 \%, 8.71 \times 10^{-3} \mathrm{M}\right), \mathrm{Cr}(\mathrm{VI})$ solution $\left(\mathrm{BDH}, 0.3 \% 1.01 \times 10^{-2} \mathrm{M}\right)$, Buffer solution $\mathrm{PH}=3$ for method A, CTC solution, $\left(2.5 \times 10^{-1} \mathrm{M}\right)$ Buffer solution $(\mathrm{pH} 2.0)$, Nitrobenzene (Qualigens) for method B and SNP Solution(E. Merck; 0.5\%, $1.678 \times 10^{-2} \mathrm{M}$ ) HA Solution, (Fluka; $0.5 \%, 7.195 \times 10^{-2} \mathrm{M}$ ) $\mathrm{Na}_{2} \mathrm{CO}_{3}$ solution (Loba; $10 \%, 9.43 \times 10^{-1} \mathrm{M}$ ) for method $\mathrm{C}$ were prepared.

\section{Recommended Procedures}

\section{Method A}

Aliquots of standard drug solution $(0.5-3.0 \mathrm{~mL} 400 \mu \mathrm{g} / \mathrm{mL})$ were delivered in to a series of centrifuge tubes and the volume in each tube was adjusted to $3.0 \mathrm{~mL}$ with $0.01 \mathrm{~N} \mathrm{HCl}$. Then $1.0 \mathrm{~mL}$ of tannic acid was added and centrifuged for $5 \mathrm{~min}$. The precipitate was collected through filtration and subsequently washed with $2.0 \mathrm{~mL}$ of distilled water. The filtrate and washings were collected in a $25 \mathrm{~mL}$ graduated test tube. Then $15 \mathrm{~mL}$ of $\mathrm{pH} 3.0$ buffer and $1.5 \mathrm{~mL}$ of PMAP solution were successively added. After $2 \mathrm{~min}, 2.0 \mathrm{~mL}$ of $\mathrm{Cr}$ (VI) solution was added and the volume was made up to the mark with distilled water. The absorbance was measured after $5 \mathrm{~min}$ at $560 \mathrm{~nm}$ against distilled water. A blank experiment was also carried out omitting the drug. The decrease in absorbance and in turn drug concentration was obtained by subtracting the absorbance of the test solution from the blank. The amount of drug was calculated from Beer's law plot (Figure 1).

\section{Method B}

Into a series of $125 \mathrm{~mL}$ separating funnels, aliquots of standard BUCZ solution (0.5-3.0 mL, $\left.100 \mu \mathrm{g} . \mathrm{mL}^{-1}\right)$ were taken. Then $2.0 \mathrm{~mL}$ of buffer $(\mathrm{pH} 2.0)$ and $5.0 \mathrm{~mL}\left(2.5 \times 10^{-1} \mathrm{M}\right)$ of CTC solutions were added. The total volume of aqueous phase in each separating funnel was adjusted to $15.0 \mathrm{~mL}$ with distilled water. To each separating funnel, $10.0 \mathrm{~mL}$ of nitrobenzene was added and the contents were shaken for $2 \mathrm{~min}$. The two phases were allowed to separate and the absorbance of the separated nitrobenzene layer was measured at $620 \mathrm{~nm}$ against a similar reagent blank. The amount of BUCZ was computed from its calibration graph (Figure 2).

\section{Method C}

Aliquots of standard BUCZ solution (1.0-6.0 mL, $\left.100 \mu \mathrm{g} \cdot \mathrm{mL}^{-1}\right)$ were transferred into a series of $25 \mathrm{~mL}$ calibrated tubes. Then $1.0 \mathrm{~mL}\left(1.678 \times 10^{-2} \mathrm{M}\right)$ of SNP and $1.0 \mathrm{~mL}\left(7.195 \times 10^{-2} \mathrm{M}\right)$ of HA were added successively and kept aside for $5 \mathrm{~min}$. Then $1.0 \mathrm{~mL}\left(9.43 \times 10^{-1} \mathrm{M}\right)$ of $\mathrm{Na}_{2} \mathrm{CO}_{3}$ solution was added and shaken for $15 \mathrm{~min}$. The volume was made up to the mark with distilled water. The absorbance was measured after $10 \mathrm{~min}$. at $440 \mathrm{~nm}$ against a similar reagent blank. The amount of BUCZ was computed from its calibration graph (Figure 3 ). 


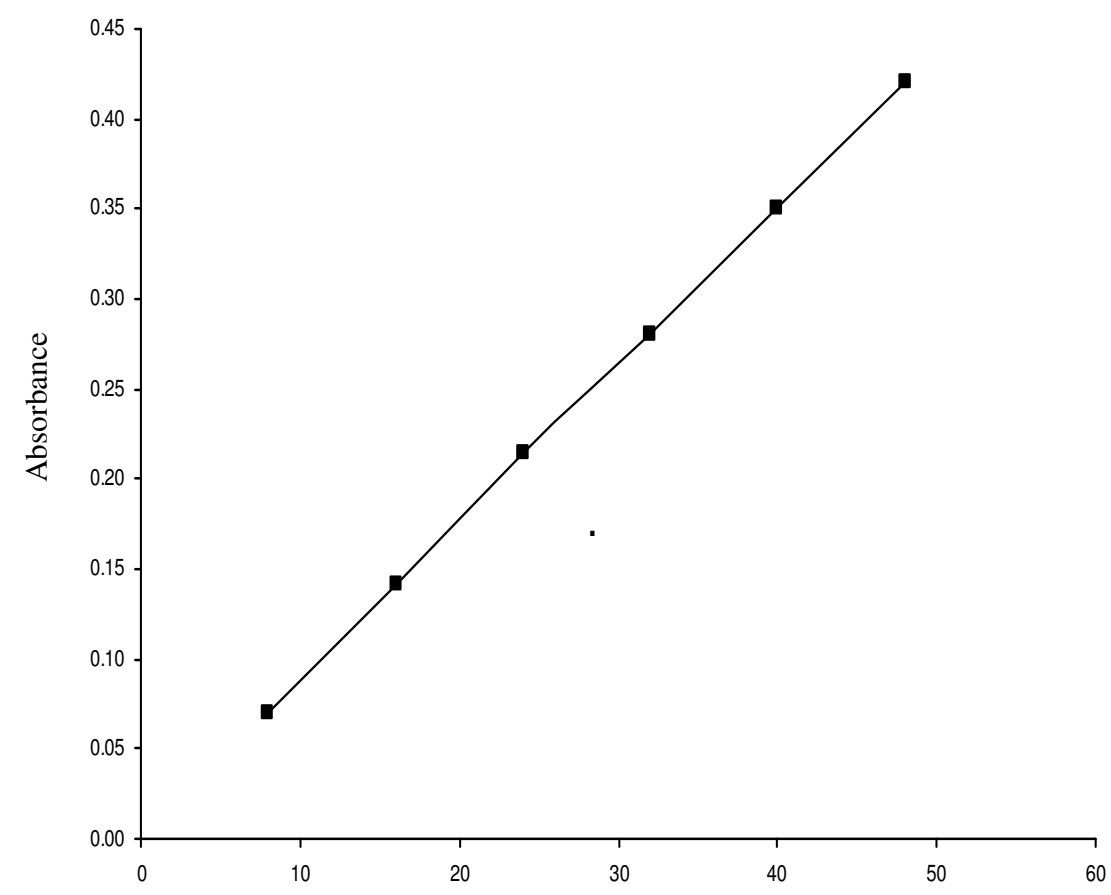

Figure 1. Beer's law plot of BUCZ - TA/PMAP - Cr (VI)

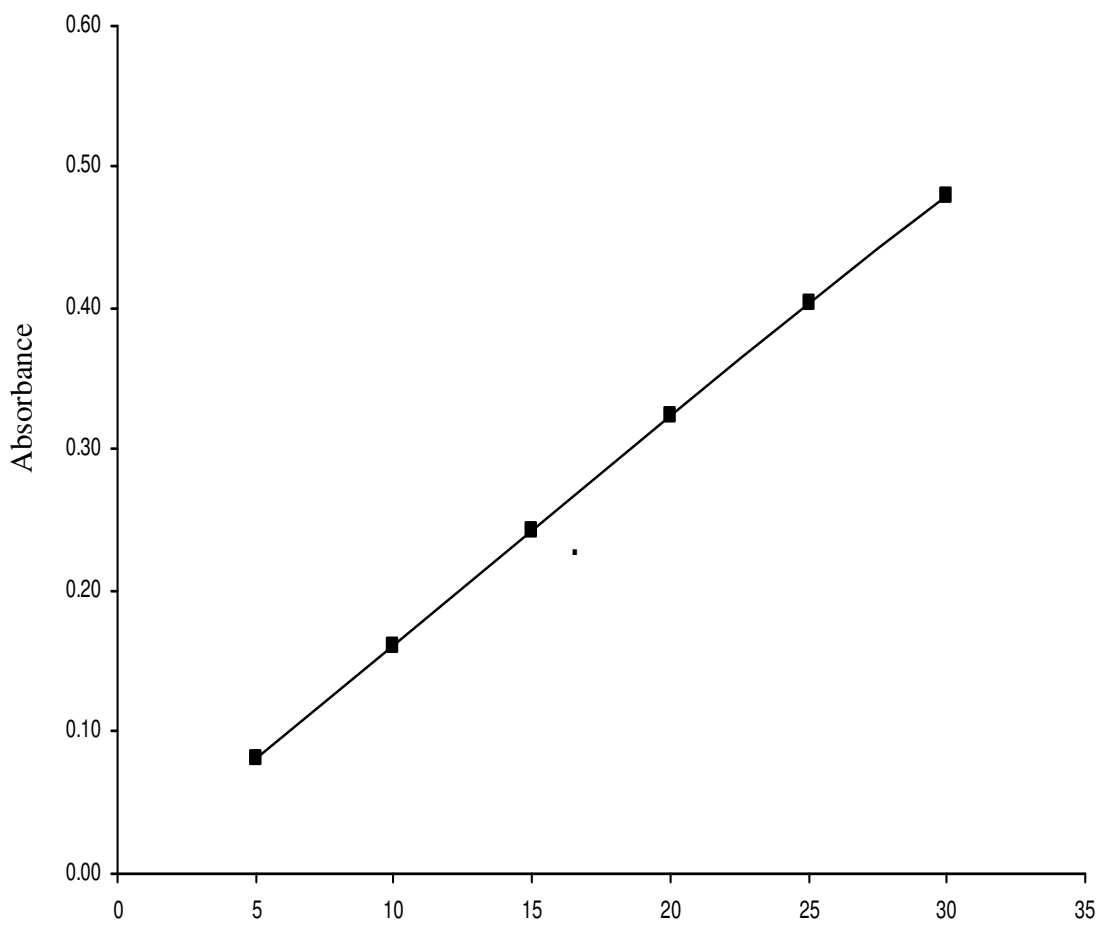

Figure 2. Beer's law plot of BUCZ - CTC 


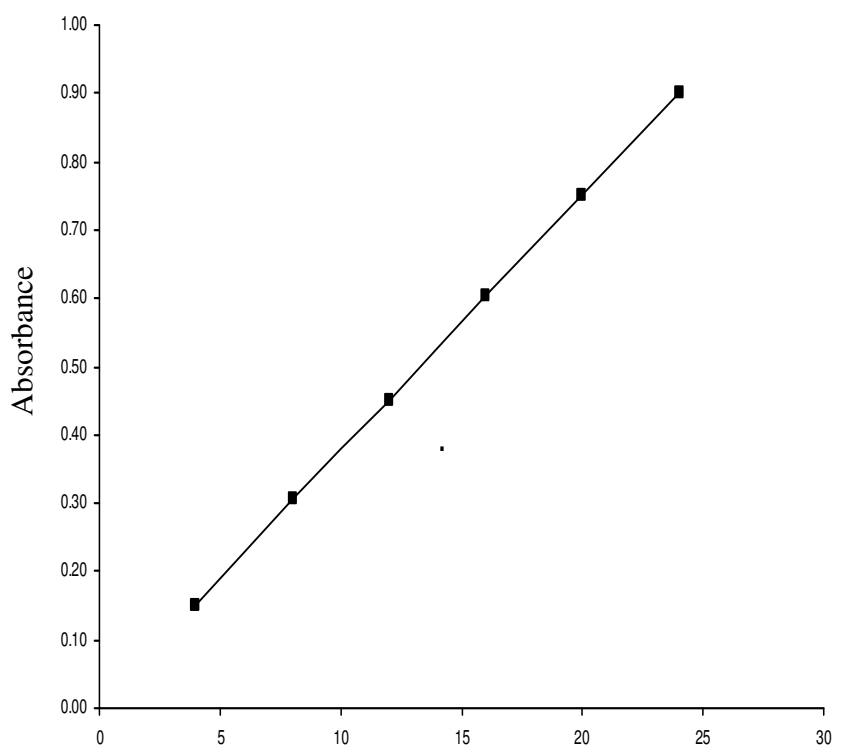

Figure 3. Beer's law plot of BUCZ - SNP - HA

Structure of $B U C Z$

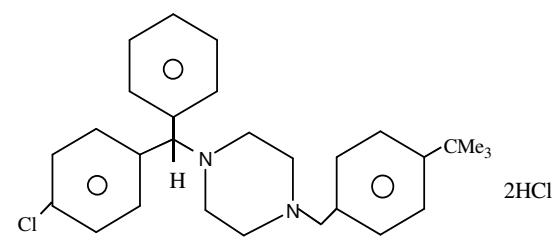

Buclizine (CAS 82-95-1): 1-[(4-chlorophenyl) Phenyl methyl] -4-[(4-(1,1 dimethyl ethyl) phenyl] methyl] piperzine;

\section{Method A}

Step I

$$
\mathrm{BUCZ}+\mathrm{TA} \rightarrow \underset{\text { (Adduct) }}{\mathrm{BUCZ}-\mathrm{TA}}+\underset{\text { (Unreacted) }}{\mathrm{TA}}
$$

\section{Step II}
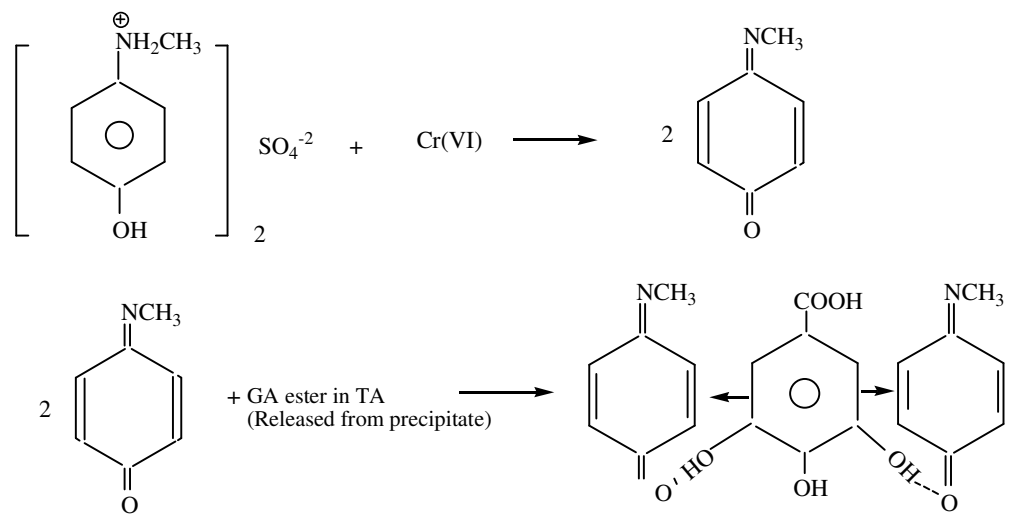


\section{Method B}<smiles>[R]N1CCN([R])CC1</smiles>

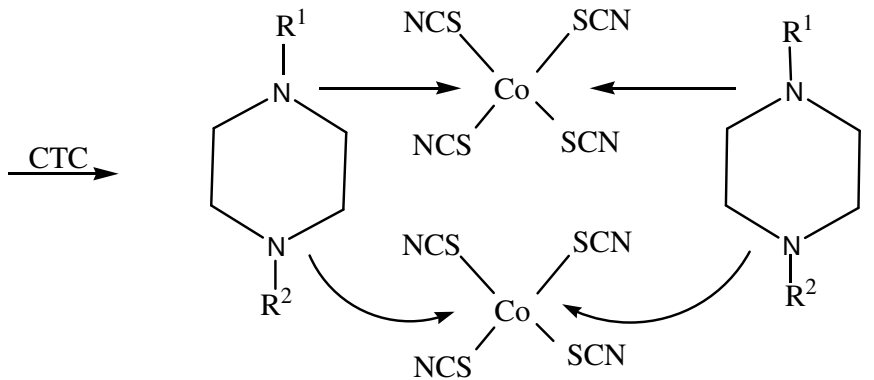

Method C

$$
\left[\mathrm{Fe}(\mathrm{CN})_{5} \mathrm{NO}\right]^{2-} \underset{\mathrm{Na}_{2} \mathrm{CO}_{3}}{\stackrel{\mathrm{NH}_{2} \mathrm{OH}}{\longrightarrow}}\left[\mathrm{Fe}(\mathrm{CN})_{5} \mathrm{H}_{2} \mathrm{O}\right]^{3-} .
$$

\section{Results and Discussion}

The optimum conditions for the color development of methods A, B and C were established by varying the parameters one at a time, keeping the others fixed and observing the effect produced on the absorbance of the colored species.

The list of proposed and reported methods was given in Table 1. The optical characteristics such as Beer's law limits, molar absoptivity and Sandell's sensitivity for the methods (A-C) are given Table 2. The precision of the method to the drug was found by measuring the absorbance of six separate samples containing known amounts of drug and the results obtained are incorporated .Regression analysis using the method of least squares was made to evaluate the slope(b), intercept(a) and correlation coefficient (r) and standard error of estimation (Se) for each system.

Table 1. Proposed and reported visible spectrophotometric methods

\begin{tabular}{ccccccc}
\hline Type of Reaction & Reagent & Method & \multicolumn{3}{c}{ Optical characteristics } \\
\cline { 5 - 7 } & & $\lambda_{\max } \mathrm{nm}$ & $\begin{array}{c}\epsilon_{\max } \\
\text { L.mole }\end{array} \mathrm{cm}^{-1}$ & $\begin{array}{c}\text { Beer's limits } \\
\mu \mathrm{g} \mathrm{mL}^{-1}\end{array}$ \\
\hline $\begin{array}{c}\text { Precipitation/charge } \\
\text { transfer complex } \\
\text { formation }\end{array}$ & $\begin{array}{c}\text { TA/Metol- } \\
\mathrm{Cr}(\mathrm{VI})\end{array}$ & $\mathrm{A}$ & 560 & $4.366 \times 10^{3}$ & $8-48$ \\
$\begin{array}{c}\text { Complex formation } \\
\text { Inner complex } \\
\text { formation }\end{array}$ & $\mathrm{CTC}$ & $\mathrm{B}$ & 620 & $8.173 \times 10^{3}$ & $5-30$ \\
\hline
\end{tabular}


Table 2. Optical and regression characteristics, precision and accuracy of the proposed methods for BUCZ

\begin{tabular}{|c|c|c|c|}
\hline Parameters & Method A & Method B & Method C \\
\hline$\lambda_{\max ,} \mathrm{nm}$ & 560 & 620 & 440 \\
\hline Beer's law limits, $\mu \mathrm{g} / \mathrm{mL}$ & $8-48$ & $5-30$ & $4-24$ \\
\hline Detection limit, $\mu \mathrm{g} / \mathrm{mL}$ & 2.475 & 3.054 & 3.809 \\
\hline Molar absorptivity, $\mathrm{Lmol}^{-1} \cdot \mathrm{cm}^{-1}$ & $4.366 \times 10^{3}$ & $8.173 \times 10^{3}$ & $1.9104 \times 10^{4}$ \\
\hline $\begin{array}{l}\text { Sandell's sensitivity }\left(\mu \mathrm{g} . \mathrm{cm}^{-2} / 0.001\right. \\
\text { absorbance unit) }\end{array}$ & 0.2377 & 0.1564 & $8.886 \times 10^{-2}$ \\
\hline Optimum photometric range $\mu \mathrm{g} / \mathrm{mL}$ & $12.6-48$ & $10-30$ & $12-24$ \\
\hline $\begin{array}{l}\text { Regression equation }(\mathrm{Y}=\mathrm{a}+\mathrm{bc}) \\
\text { slope }(\mathrm{b})\end{array}$ & 0.0221 & 0.019755 & 0.03619 \\
\hline Standard deviation on slope $\left(\mathrm{S}_{\mathrm{b}}\right)$ & $2.518 \times 10^{-4}$ & $1.113 \times 10^{-2}$ & $3.224 \times 10^{-2}$ \\
\hline Intercept (a) & $1.4 \times 10^{-2}$ & $1.625 \times 10^{-3}$ & $2.5 \times 10^{-3}$ \\
\hline Standard deviation on intercept $\left(S_{a}\right)$ & $6.682 \times 10^{-3}$ & $1.845 \times 10^{-1}$ & $4.277 \times 10^{-2}$ \\
\hline Standard error on estimation $\left(\mathrm{S}_{\mathrm{e}}\right)$ & $6.371 \times 10^{-3}$ & $1.759 \times 10^{-1}$ & $4.079 \times 10^{-2}$ \\
\hline Correlation coefficient $(r)$ & 0.9989 & 0.9611 & 0.9646 \\
\hline Relative standard deviation (\%) & 1.072 & 1.207 & 4425 \\
\hline 0.05 level & 1.232 & 1.388 & 0.5088 \\
\hline 0.01 level & 1.933 & 2.176 & 1.7979 \\
\hline$\%$ Error in Bulk samples & -0.143 & 0.166 & 0.10 \\
\hline
\end{tabular}

The accuracy of the methods was ascertained by comparing the results by proposed and reference methods statistically by the $t$ - and $f$ - tests. The comparison shows that there is no significant difference between the results of studied methods and those of the reference ones. The similarity of the results is obvious evidence that during the application of these methods, the excipients are usually present in pharmaceutical formulations do not interfere in the assay of proposed methods. As an additional check of accuracy of the proposed methods, recovery experiments were carried out. The recovery of the added amounts of standard drug was studied at 3 different levels. Each level was repeated for six times. From the amount of drug found, the \% recovery was calculated in the usual way.

The higher $\lambda_{\max }$ values of all the proposed methods have a decisive advantage since the interference from the associated ingredients should be generally less at higher wavelengths than at lower wavelengths. Thus the proposed visible spectrophotometric methods are simple and sensitive with reasonable precision, accuracy and constitute better alternatives to the existing ones to the routine determination of BUCZ in bulk forms and pharmaceutical formulations.

\section{Conclusion}

The proposed methods exploit the various functional groups in BUCZ molecule. The decreasing order of sensitivity $\left(\epsilon_{\max }\right)$ among the proposed methods are (MethodA > Method B > Method C) respectively. The concomitants which do not contain the functional groups chosen in the present investigation do not interfere in the color development by proposed methods. Thus the proposed methods are simple, sensitive and selective with reasonable precision and accuracy and constitute better alternatives to the reported ones in the assay of BUCZ in bulk form and pharmaceutical formulations (Table 3). 
Table 3. Assay of BUCZ in pharmaceutical formulations.

\begin{tabular}{|c|c|c|c|c|c|c|c|c|}
\hline \multirow{2}{*}{ 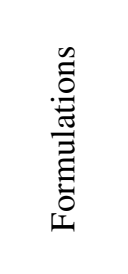 } & \multirow{2}{*}{ 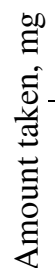 } & \multicolumn{4}{|c|}{ Amount found by proposed Methods } & \multicolumn{3}{|c|}{$\begin{array}{l}\text { Percentage recovery by } \\
\text { proposed methods }\end{array}$} \\
\hline & & Method A & Method B & Method C & $\begin{array}{c}\text { Reference } \\
\text { Method }\end{array}$ & $\begin{array}{c}\text { Method } \\
\text { A }\end{array}$ & $\begin{array}{c}\text { Method } \\
\text { B }\end{array}$ & $\begin{array}{l}\text { Method } \\
\text { C }\end{array}$ \\
\hline Tablet I & 25 & $\begin{array}{l}25.04 \pm 0.39 \\
F=1.710 \\
t=0.3464\end{array}$ & $\begin{array}{l}24.57 \pm 0.33 \\
F=1.777 \\
t=1.619\end{array}$ & $\begin{array}{l}24.80 \pm 0.22 \\
F=4.0 \\
t=0.682\end{array}$ & $24.95 \pm 0.51$ & $99.72 \pm 0.99$ & $99.55 \pm 0.99$ & $99.73 \pm 0.98$ \\
\hline Tablet II & 25 & $\begin{array}{l}24.56 \pm 0.44 \\
F=1.9855 \\
t=1.176\end{array}$ & $\begin{array}{l}24.63 \pm 0.42 \\
F=3.0209 \\
t=1.807\end{array}$ & $\begin{array}{l}24.92 \pm 0.63 \\
F=1.342 \\
t=0.7895\end{array}$ & $24.92 \pm 0.62$ & $99.73 \pm 0.98$ & $99.85 \pm 0.61$ & $99.82 \pm 0.44$ \\
\hline Tablet III & 25 & $\begin{array}{l}24.78+0.31 \\
F=2.298 \\
t=1.509\end{array}$ & $\begin{array}{l}24.72+0.43 \\
F=1.6538 \\
t=0.60\end{array}$ & $\begin{array}{l}24.37 \pm 0.41 \\
F=1.819 \\
t=0.64\end{array}$ & $25.12 \pm 0.47$ & $99.89 \pm 0.61$ & $99.93 \pm 0.85$ & $99.72 \pm 0.53$ \\
\hline Tablet IV & 25 & $\begin{array}{l}25.28 \pm 0.54 \\
F=2.305 \\
t=0.9678\end{array}$ & $\begin{array}{l}24.63 \pm 0.22 \\
F=1.506 \\
t=0.700\end{array}$ & $\begin{array}{l}24.93 \pm 0.14 \\
F=3.719 \\
t=1.520\end{array}$ & $24.90 \pm 0.82$ & $99.75 \pm 0.53$ & $99.73 \pm 0.65$ & $99.88 \pm 0.84$ \\
\hline
\end{tabular}

\section{References}

1 The Merck Index, Merck \&Co Inc, New York Ed., 2001, 13, 1803.

2 Aly F A, Mikrochim Acta, 1993, 110, 187-192.

3 Prasada Rao K V S, Nagaraju P, Prabhakar G, Begum J and Rasheed A, J Inst Chemists., 2004, 76, 19.

4 Matsuda R, Yamamiya T, Tatsuzawa M, Ejima A and Takai N, J Chromatogr., 1979, 173A, 75.

5 Angelo H R, Herrstedt and Erich J, GIT, Spez Chromatogr. B, 1989, 496, 472.

6 Li Wan Po A and Irwin W J, High Resolut, Chromatogr., 1979, 2, 623.

7 Kaniewska T and Wejman W, Pol Farm, 1974, 30, 763.

8 Eblant-Goragia A, Balant L P Gent C and R. Eisele R, Ther Drug Monit., 1985, 7 229-235.

9 Shehata I A, El-Ashry S M, Sherbeny M A, EL Sherbeny D T and Belal F, J Pharm Biomed Anal., 2000, 22, 729-737.

10 Hassan S M, Belal F, Ibrahim F and Aly F A, Talanta, 1989, 36, 557.

11 Belal F, Ibrahim, Hassan S M and. Aly F A, Anal Chim Acta, 1991, 55, 103.

12 Kumazawa T, Seno H., Watanabe S, Kanako H, Hideki H, Akira S and Keizo O, $J$ Mass Spectrom., 2000, 35, 1091.

13 Clean S, Kane E J O and Smyth W F, J Chromatogr B Biomed Sci Appl., 2000, 740, 141.

14 Maurev H and Pfleger K, J Chromatogr., 1985, 306,.125.

15 Cailleux A, Turcant A, Premel-Cabic A and Allain P, J Chromatogr Sci, 1981, 19, 163.

16 El-Sherif Z. A., EL - Zeany B, EL-Houssinl O M, Rashed M S and Aboul-Enein H Y, Biomed chrom., 2004, 18(3),143.

17 Janiszewski J, Schneider R P, Haffmaster K, Swyden, M, Wells D and Fouda H, Mass Spectrom., 1997, 11(9), 1033. 


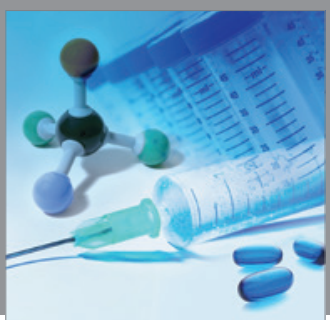

International Journal of

Medicinal Chemistry

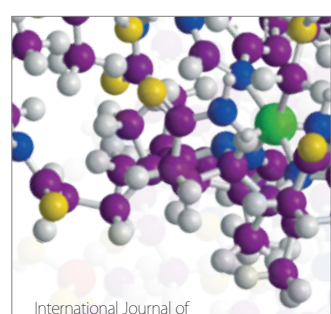

Carbohydrate Chemistry

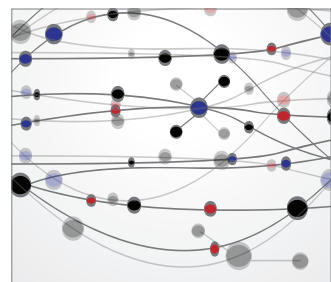

The Scientific World Journal
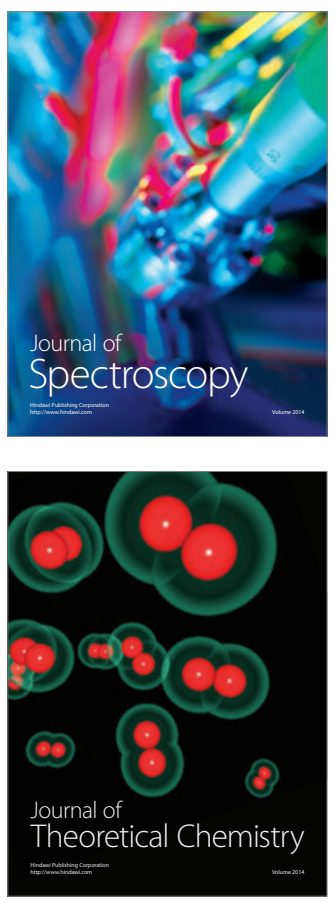
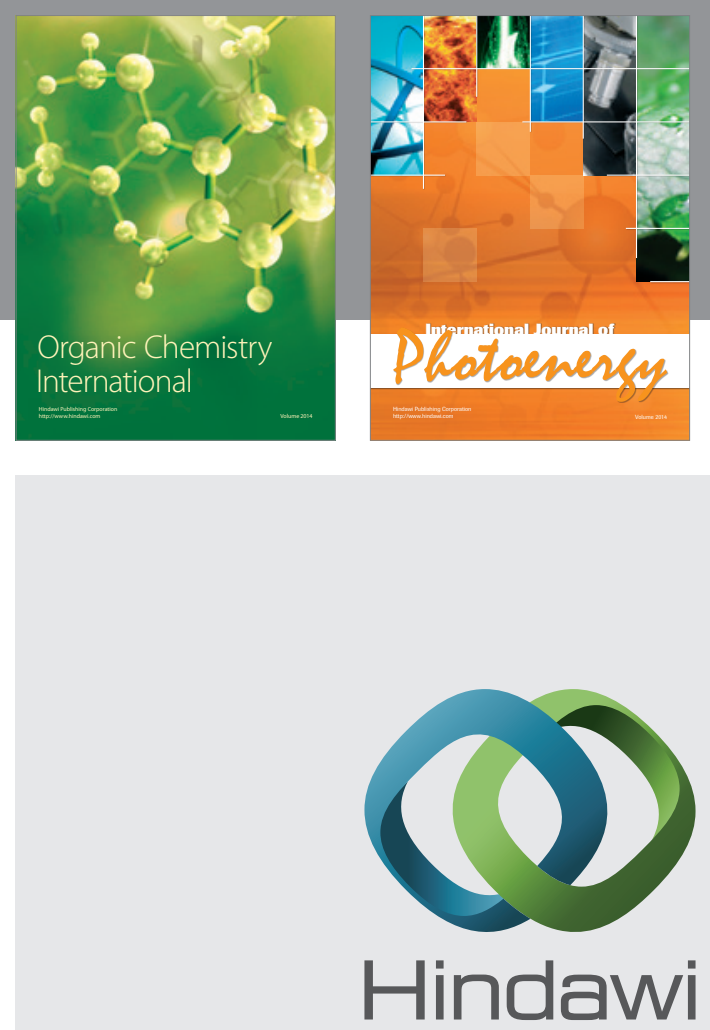

Submit your manuscripts at

http://www.hindawi.com
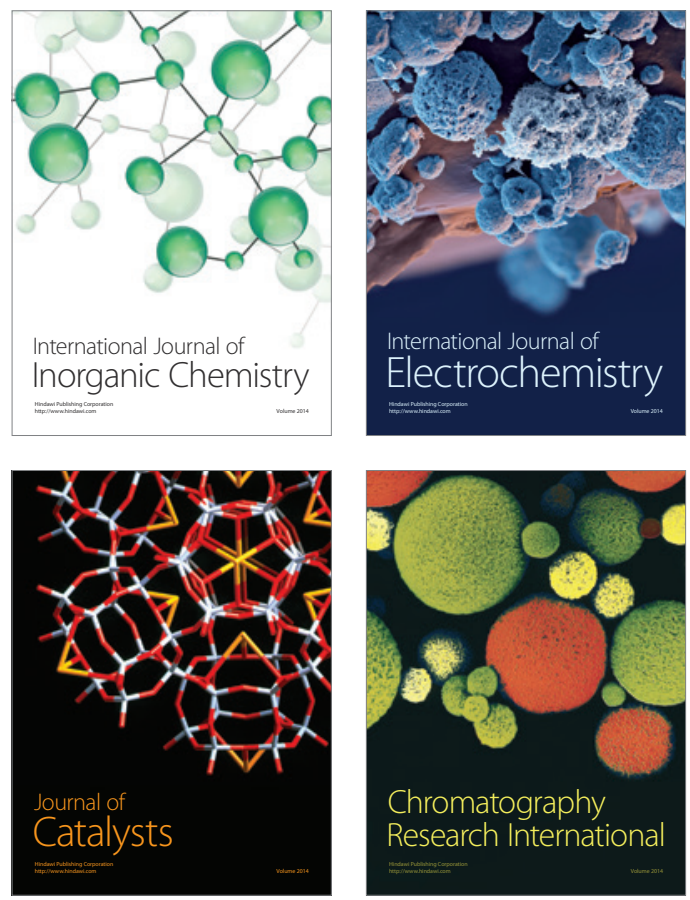
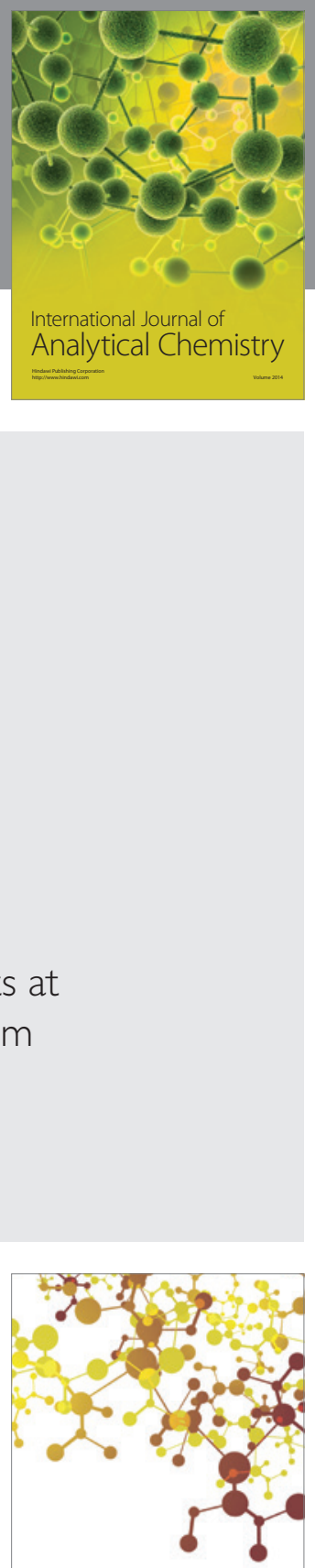

Journal of

Applied Chemistry
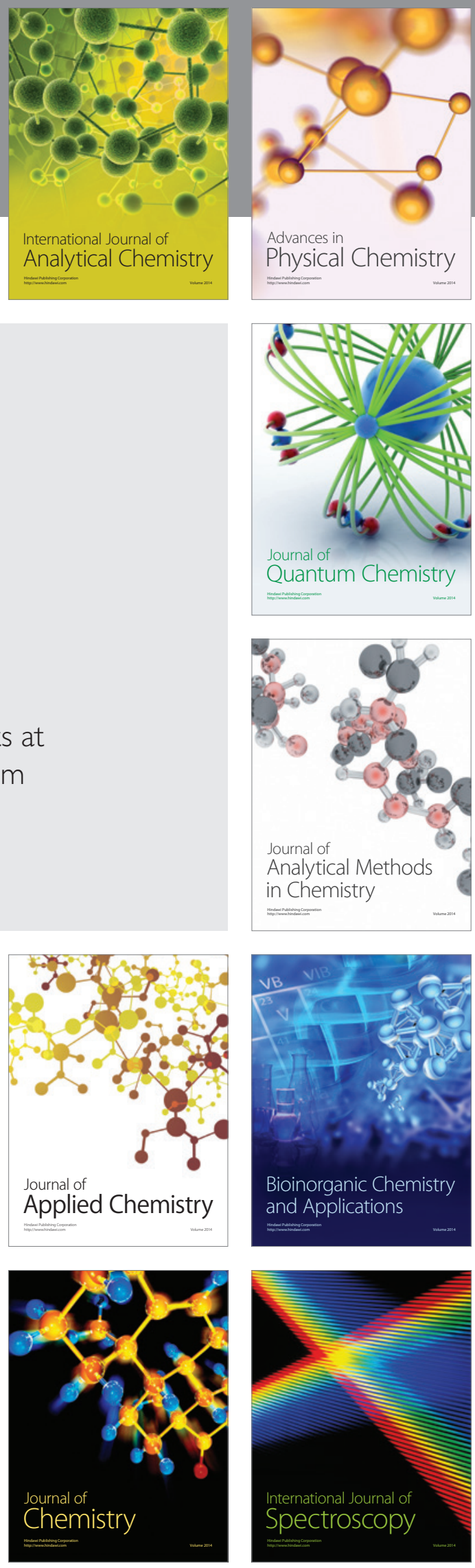